\title{
OPEN Research progress on applications of calcium derived from marine organisms
}

\author{
Yangli Xu${ }^{1}$, Jian $\mathrm{Ye}^{1}$, Deqing Zhou ${ }^{2} \&$ Laijin Su${ }^{3 凶}$ \\ Calcium is an important mineral that plays an integral role in human health, especially bone health. \\ Marine biological calcium is an abundant resource that is generally accepted and has a complex active \\ structure. This review evaluates research progress on marine biological calcium with regards to its \\ sources, use of calcium supplements, calcium bioavailability, and novel applications of marine calcium. \\ The potential for future development and the use of products incorporating marine biological calcium \\ in biomedical research and the pharmaceutical, health care, and food industries are also reviewed. The \\ goal of this review is to provide a comprehensive documentation on resource utilization and product \\ development from marine organisms.
}

Calcium is an important micronutrient widely believed to affect bone health and human metabolism. Calcium deficiency can cause conditions like osteoporosis, rickets, epilepsy, and anemia. Calcium enters the circulation through food or calcium supplements, and a dynamic balance is maintained between blood and bone calcium ${ }^{1}$. The primary source of calcium is dairy products, including milk and its by-products like cheese and condensed milk, followed by other sources like cereals and tofu ${ }^{2}$. However, an inappropriate diet can decrease the bioavailability of calcium. For example, the presence of phytic acid in cereals and oxalic acid in green leafy vegetables can cause calcium to precipitate as calcium phytate and calcium oxalate, which are insoluble compounds ${ }^{3}$. In America, a study found that approximately $38 \%$ of adults who rely solely on food for mineral and vitamin intake consume inadequate levels of calcium, and approximately $93 \%$ consume inadequate levels of vitamin $\mathrm{D}$, which plays a key role in calcium absorption rate, bone homeostasis, and bone repair ${ }^{4,5}$. Calcium deficiency becomes gradually debilitating with age ${ }^{6}$. Chronic calcium deficiency has caused osteoporosis to become an epidemic ${ }^{7}$. An increasing number of people continue to face calcium deficiency and diseases associated with calcium deficiency ${ }^{8-10}$. As a result, more people have increased their calcium intake through supplements based on the advice of doctors or the media ${ }^{11}$.

The calcium sources for these supplements include calcium carbonate ores, calcium-rich animal skeletons, marine shells, and crustaceans ${ }^{12}$. However, natural calcium carbonate ores may contain harmful elements, such as heavy metals ${ }^{13}$. Animal bones may carry the risk of prion transmission ${ }^{14,15}$. In recent years, calcium supplements from marine sources have gained attention due to their abundant reserves, high safety, and biological activity ${ }^{16,17}$. With the development and utilization of marine resources, more than $50 \%$ of fishery products, including bones, fins, heads, and internal organs, which are discarded as waste annually, can be used. Marine mineral supplements have the potential to increase bone turnover and may aid in preventing injuries and repairing damaged bone in humans ${ }^{18}$. As an abundant source of calcium, the use of marine biological calcium is an important way to improve the utilization rate of biological resources. This review comprehensively evaluates the marine calcium sources, the technology used for the preparation of calcium supplements, and the biological activity and bioavailability of marine calcium to provide references for the effective development of supplements using marine calcium.

\section{Marine source of calcium}

Oceans are rich in biological resources and calcium is an important mineral constituent of marine life. The major sources of calcium for humans from the oceans include fishbones, shellfish and crustacean shells, and coral and seaweed (Fig. 1).

\footnotetext{
${ }^{1}$ Wenzhou Characteristic Food Resources Engineering and Technology Research Centre, Wenzhou Academy of Agricultural Sciences, Wenzhou 325006, China. ${ }^{2}$ Laboratory for Marine Drugs and Bioproducts of Qingdao National Laboratory for Marine Science and Technology, Yellow Sea Fisheries Research Institute, Chinese Academy of Fishery Sciences, Qingdao 266071, China. ${ }^{3}$ College of Life and Environmental Science, Wenzhou University, Wenzhou 325035, China. ${ }^{\varpi}$ email: sulaijin@126.com
} 


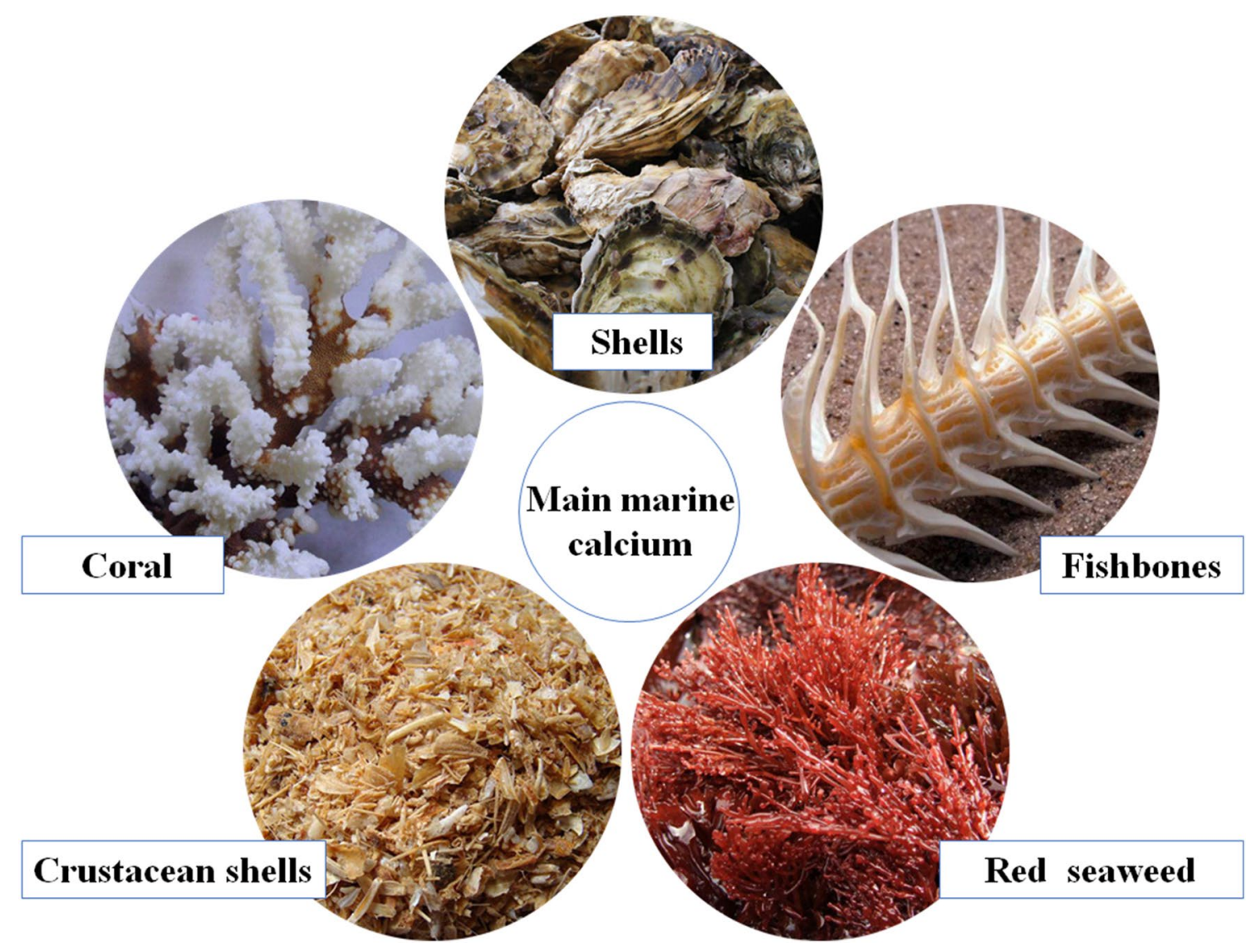

Figure 1. Main calcium source from Marine organism.

Calcium from fishbones. Fishbone is the general term encompassing the axial, appendage, and fishbone in the fish body, accounting for approximately $10-15 \%$ of the total body weight ${ }^{19}$. Fishbone tissue consists mainly of an organic extracellular matrix covered with hydroxyapatite $\left[\mathrm{Ca}_{5}\left(\mathrm{PO}_{4}\right)_{3} \mathrm{OH}\right]$ and the calcium content found to be lowest in the salmonid species when compared to eight different species of fish was as high as $135-147 \mathrm{~g} / \mathrm{kg}$ in the lipid-free dry matter ${ }^{20}$. Shark cartilage is another important source of calcium. For example, the calcium from the jaw cartilage of gummy shark is mainly in the form of hydroxy calcium phosphate crystal $\left[\mathrm{Ca} 10(\mathrm{PO} 4)_{6}(\mathrm{OH})_{2}\right]$, and its calcium phosphate content is among the highest with $67 \%$ on a dry weight basis, which ranges between 124 and $258 \mathrm{~g} / \mathrm{kg}^{21}$. Fishbones from large fishes need to be processed using chemical and biological methods to destroy organic material or bonded with collagen to increase the calcium dissolution rate because calcium in the form of hydroxyapatite is not suitable for absorption in humans ${ }^{22}$. Small fishes with soft bones, such as anchovies and lizardfish, can be processed into ready-to-eat food to be consumed with their bones $^{23}$. Generally, calcium preparation from fishbones includes the removal of protein and fat by cooking, treating with alkali and organic solvents or enzymatic hydrolysis, and superfine crushing to obtain a fishbone powder.

Calcium from shells. Shells account for approximately $60 \%$ of the mass of a shellfish, and calcium carbonate content in a shell can reach $95 \%$. Shells are a rich source of high-quality marine calcium. Shellfish culture offers humans a low-impact source of sustainable protein ${ }^{24}$. In 2016, farmed shellfish reached 17.139 million tons globally, accounting for $21.42 \%$ of the total farm output ${ }^{25}$. Additionally, as the proportion of calcium in shells is higher than that in fishbones, the output from shells is greater ${ }^{26,27}$. The effects of calcium supplementation with Ezo giant scallop shell powder and fossil shellfish powder have been studied; the results indicated good solubility and bioavailability of calcium from these natural sources of calcium ${ }^{28}$. The shell calcium supplement was marketed in several countries worldwide; however, the utilization of shell resources remains low, and the comprehensive utilization and development of shell calcium require further support.

Calcium from crustacean shells. People can directly ingest calcium by eating small dried shrimp or crabs. Crustacean processing and consumption generate $30-40 \%$ of marine resource waste ${ }^{29}$. Crustacean shells mainly comprise calcium carbonate $\left(\mathrm{CaCO}_{3}\right)$, chitin, and protein ${ }^{30}$. Research on shrimp and crab shells have mainly focused on the utilization of chitin and protein resources, while calcium is sometimes recycled as a byproduct, such as calcium hydrogen phosphate, calcium lactate, and calcium ${ }^{31}$.

Calcium from coral. Coral calcium is formed from the exoskeleton of living organisms of many species ${ }^{32}$. Coral calcium is a natural source of marine calcium, containing $24 \%$ calcium, $12 \%$ magnesium, and more than 


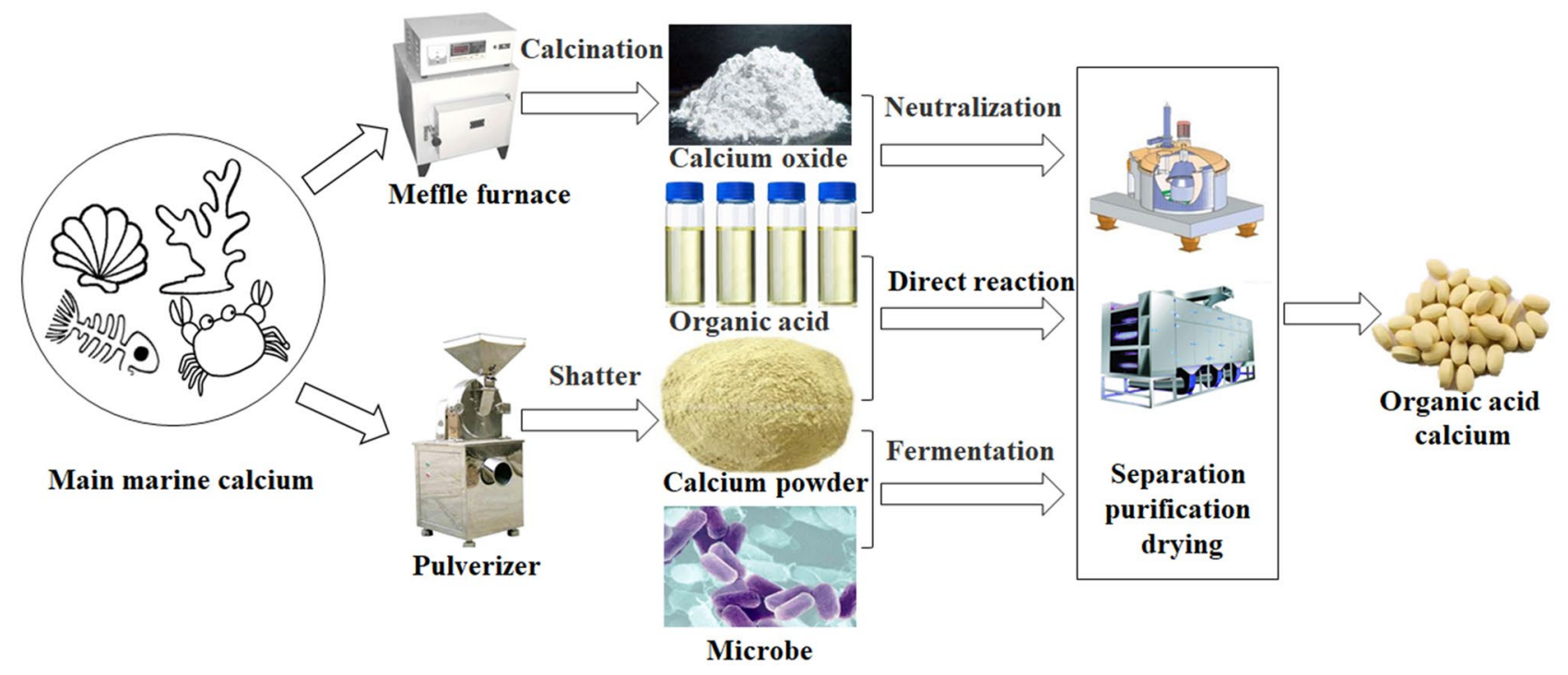

Figure 2. Flow chart of preparation of calcium organic acid from Marine calcium.

70 minerals; it has recently become a new international trend of calcium supplementation. Coral calcium is often used as a calcium supplement to treat bone metabolism disorders, osteoporosis, and other bone diseases ${ }^{33,34}$.

Calcium from seaweed. Seaweed from the ocean, especially green algae, is rich in minerals such as calcium $^{35}$. For example, Aquamin, a typical calcium-rich supplement derived from the calcified skeletal remains of the red seaweed species Lithothamnion, has calcium concentrations of up to $31 \% /$ weight $^{36}$. A previous study has indicated that concerning calcium sources for horses, marine algae is better than calcium carbonate supplements ${ }^{37}$. Calcium extracted from marine algae was also found to show a beneficial anabolic effect on bone skeletal calcification in animal models of osteoporosis ${ }^{38}$. Algal calcium prepared from oyster shell powder and seaweed has a higher bioavailability than calcium carbonate ${ }^{39}$.

\section{Calcium supplements and bioavailability}

Direct ingestion of marine-derived calcium. The most common direct calcium supplements are small dried shrimp, shell powder, and small fishes. Several marine calcium supplements, such as oyster shells and coral calcium, have been commercialized in different countries. However, the main components derived from these marine sources are calcium carbonate and calcium polyhydroxy phosphate, which are difficult to absorb and increase gastric burden ${ }^{40}$. To improve the calcium absorption rate, marine sources are typically crushed or vacuum heated first ${ }^{41,42}$. Studies have found that marine-derived calcium has certain advantages over calcium carbonate supplements or other calcium-rich food. For example, Aquamin has better bioavailability and potential to slow down bone loss compared to calcium carbonate ${ }^{36}$. Hake fishbone (HBF) was a good source of calcium, with comparable efficacy to Lithotame (L), a calcium supplement derived from Lithothamnion calcar$\mathrm{eum}^{17}$. A fishbone powder (Phoscalim) and a ray cartilage hydrolysate (Glycollagene) were comparable to milk for both short-term calcium absorption and bone resorption ${ }^{16}$. Tablets made with calcium from haddock bones were adequate for calcium supplementation and osteoporosis prevention ${ }^{43}$. Currently, the international recommended daily intake of calcium for general population is 700-1200 mg per day. However, teenagers (9-18 years old) need approximately $1300 \mathrm{mg}$ calcium per day, and pregnant women with low dietary calcium intake need $1500-2000 \mathrm{mg}$ calcium per day ${ }^{44,45}$. Studies have shown that more than $50 \%$ of the calcium deficient population include men and women older than 70 years, women aged 51-70 years, boys and girls aged 9-13 years, and girls aged $14-18$ years $^{46}$. Taking a conscious supplement of marine calcium is very effective in preventing calcium deficiency. Direct calcium ingestion from marine organisms is very suitable for daily calcium supplementation; however, it is insufficient for treating calcium deficiency diseases. In the treatment of diseases such as calcium deficiency, there is also a need to choose higher doses of calcium supplements or drugs ${ }^{5}$.

Organic acid calcium. Organic acid calcium, such as calcium citrate, L-calcium lactate, calcium gluconate, calcium acetate, calcium formate, and calcium propionate, have higher bioavailability, solubility, and absorption rates, regardless of gastric contents, because they are less sensitive to gastric $\mathrm{pH}$ than calcium carbonate ${ }^{11,40,47}$. It is mainly prepared by neutralization or fermentation of calcium compounds (Fig. 2). As a dietary calcium supplement, calcium formate has been found to exhibit significant advantages over both calcium carbonate and calcium citrate $^{48}$. Calcium glucoheptonate has exhibited a high relative bioavailability of calcium and is welltolerated in humans than calcium carbonate ${ }^{49}$. However, calcium gluconate and calcium lactate are less concentrated forms of calcium, making them impractical oral supplements. Calcium acetate and calcium propionate are not widely used either ${ }^{50}$. Calcium organic acids alone are not good for absorption because they can bind to oxalic acid or phytic acid present in food. Calcium combined two or more organic acids, such as calcium citrate malate 


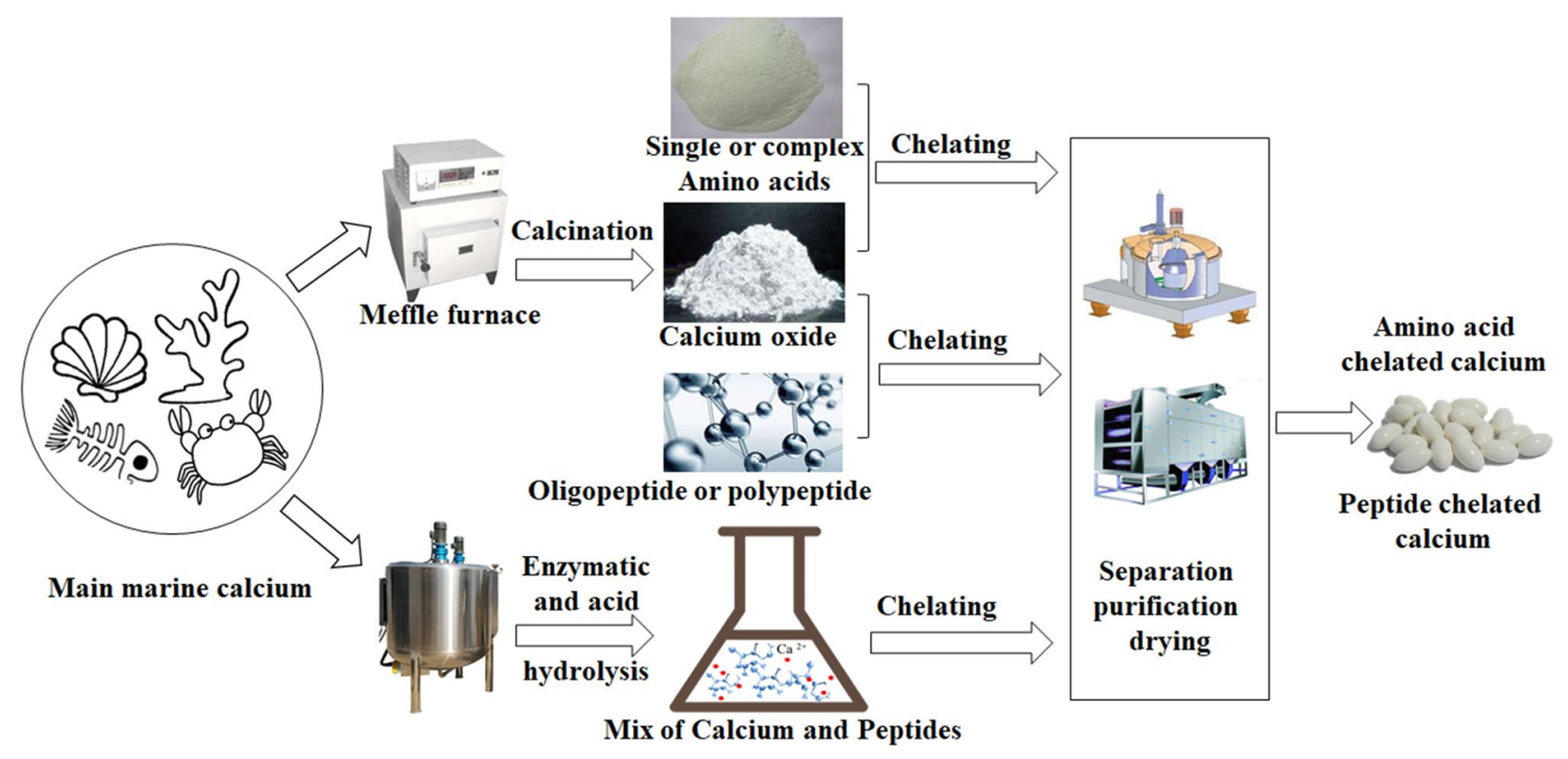

Figure 3. Flow chart of preparation of chelate calcium from Marine calcium.

$(\mathrm{CCM})^{10}$, which combines bovine collagen peptides with calcium citrate ${ }^{51,52}$. The combined use of polycan and calcium lactate-gluconate ${ }^{53,54}$ was found to have beneficial synergistic effects compared with the use of calcium organic acids alone.

Marine sources of calcium organic acids are primarily fishbones, shrimp, crab shells, and other shells ${ }^{3}$. To facilitate easy calcium absorption, appropriate processes such as calcination, enzymatic hydrolysis and fermentation methods should be selected according to the nutritional composition and associated processing properties $^{55,56}$. Subsequently, citric acid, gluconic acid, lactic acid, acetic acid, and/or propionic acid are added to prepare calcium organic acids. The solubility and bioavailability of calcium from natural sources of shellfish calcium with citrate and lactate were increased after decompression treatment ${ }^{26}$. Fishbones can be fermented with Leuconostoc mesenteroides to obtain high amounts of soluble calcium with free calcium, calcium amino acids, calcium acetate, small peptide calcium, and calcium lactate. The fermentation of grass fishbones can increase calcium bioavailability and also help avoid wastage of fishbone calcium and aquatic protein $\mathrm{s}^{57}$.

Calcium chelate. Calcium chelate refers to the metal complex formed by stable bonds between amino acids or peptides and metal calcium ions and includes two main products, calcium amino acid and calcium peptide chelate $^{58-60}$. It is mainly prepared by chelating polypeptides or oligopeptides with calcium ions or when a single or complex amino acid chelates with calcium ions (Fig. 3). Amino acid chelated calcium is not dependent on vitamin D3 and can be absorbed by the human body through amino acid metabolism. For example, calcium lysinate, a new form of calcium preparation, may have better absorption, making it a better calcium supplement than calcium carbonate and $\mathrm{CCM}^{61}$. However, peptide chelated calcium has advantages over other calcium supplements ${ }^{62-64}$. A growing number of chelating peptides have been identified and have been shown to promote and improve mineral bioavailability ${ }^{65,66}$. The calcium peptide chelate produced by combining fishbone calcium and calcium-binding bone collagen peptide through enzymatic hydrolysis demonstrated improvement in calcium bioavailability ${ }^{67-69}$. The algae peptide-based calcium-chelating complex and calcium alginate nanoparticles have the potential to be utilized as a calcium supplement to improve bone health ${ }^{70-72}$. However, the production cost of peptide chelated calcium is high, and the yield is low. With the development of new preparation technology, peptide chelated calcium will likely become a good calcium supplement.

\section{Other functions of marine source calcium}

Biological activity. Marine biological calcium has biological functions other than improving calcium homeostasis and bone health. For example, coral calcium was shown to regulate blood pressure and prevent the metastasis of colon cancer ${ }^{30,73,74}$. Calcium spirulan, derived from Spirulina platensis (Arthrospira platensis), a filamentous blue-green microalga from rivers and lakes, was shown to inhibit herpes simplex virus 1 actively, and possibly, infections caused by other herpesviruses ${ }^{75}$. Coral calcium hydroxide can act as an antioxidant, slowing senescence in mice and preventing hepatic steatosis ${ }^{76-78}$. The calcium oxide made from scallop shells was shown to inhibit Pseudomonas aeruginosa, a spoilage bacterium for eggs with a strong resistance to chemical agents such as sanitizers and disinfectants ${ }^{79}$. Calcium derived from oysters exhibited good efficacy in suppressing the formation and proliferation of oral squamous cell carcinoma ${ }^{80}$. 


\begin{tabular}{|c|c|c|c|c|}
\hline Name & Brand & Country & Calcium form & Source \\
\hline Calcium carbonate & Life & Canada & Oyster shell powder, VD3 & Oyster shells \\
\hline Calcian + D3 & Jamieson & Canada & $\begin{array}{l}\text { Calcium citrate, calcium malate, fumaric acid calcium, calcium succinate, } \\
\text { calcium carbonate, VD3 }\end{array}$ & Oyster shells \\
\hline Natural calcium & FOR BECARED ONE & USA & VD3, calcium, collagen type II & Oyster shells \\
\hline Shen Gu Pian & Duo Yuan Kang & China & Oyster shell powder & Oyster shells \\
\hline MC calcium & MC & Japan & Oyster shell powder, ursodeoxycholic acid, lysine hydrochloride & Oyster shells \\
\hline Coral calcium capsules & Catalo & USA & $100 \%$ pure coral powder & Coral \\
\hline Coral calcium & Holland and Barrett & UK & $100 \%$ pure coral powder & Coral \\
\hline $\begin{array}{l}\text { Haibrusk } \\
\text { Shark cartilage }\end{array}$ & Bjorge ocean & Norway & Shark cartilage powder & Shark cartilage \\
\hline Bonecare Kids calcium complex chews & Clinicians & New Zealand & $\begin{array}{l}\text { Calcified lithothamnion, alcarerum-red algae, trimagnesium citrate, boron } \\
\text { citrate, zinc amino acid chelate, manganese amino acid chelate, VD3 }\end{array}$ & Red algae \\
\hline Atomy tri-active calcium & Atomy & Korea & Seaweed meal, magnesium oxide, calcium citrate, serum calcium, VD & Red algae \\
\hline
\end{tabular}

Table 1. Common commercial calcium supplements from Marine sources.

New materials. Calcium from marine sources can serve as a raw material for the production of highvalue-added compounds that can be used in biomedical research and pharmaceutical, healthcare, and food industries ${ }^{81}$. Previous studies have found a huge potential for producing porous scaffolds from oyster shells, clamshells, cuttlefish bones, and salmon bones ${ }^{82-85}$. The structural features of these scaffolds were found to be conducive to improve biological activities, including mechanical properties, and bone tissue growth and vascularization $^{86}$. The production of natural hydroxyapatite (nHAP) from salmon bones and rainbow trout has a great potential as bone implant material substitutes in bone tissue engineering ${ }^{87}$. Marine biological calcium can also be used to prepare adsorption materials, demonstrating its potentially wide applications in water treatment. For example, calcium-rich biochar prepared from crab shells can be used to remove dyes and phosphorus from wastewater $^{88,89}$. The acid-insoluble calcium silicate hydrates synthesized from oyster shells were also applicable in removing organic pollutants and heavy metal ions ${ }^{90}$. Single-phase hydroxyapatite (HA) and biphasic calcium phosphate (HA/ $\beta$-TCP), which are derived from Atlantic cod bones, have no known cytotoxic effects and have demonstrated good bioactivity in simulated body fluid ${ }^{91}$. Consequently, calcium phosphate derived from marine organisms has a promising future in fabricating bacterial infection-resistant bone substitutes or bone defect healing. $\mathrm{HA}\left(\mathrm{Ca}_{10}\left(\mathrm{PO}_{4}\right)_{6}(\mathrm{OH})_{2}\right.$, HAp) derived from codfish bones is a calcium phosphate, which is a safer option for sunscreen formulation, indicating its potential across a wide range of applications in health care products and $\operatorname{cosmetics}^{92}$.

Food additives. Biological calcium from marine processing waste can still be used in food processing. For example, fish bones can be added to fish surimi to improve the gel performance of the product ${ }^{93}$. Oyster shell calcium powder can improve the chewiness and springiness of restructured ham ${ }^{94}$. Calcium-rich shrimp and crab shells can also be used to prepare food flocculants ${ }^{95}$. There are many food additives containing calcium, such as calcium carbonate, calcium silicate, calcium sulphate, and calcium lactate. The calcium additives from marine organisms may be safer because they have a natural origin.

\section{Conclusions and future perspectives}

Marine processing waste is often considered useless; however, it is an abundant and low-cost source of calcium. A study found that 55 brands of calcium supplements can be classified into seven categories based on the major ingredient in them and three or more categories were found to be derived from marine organisms mainly oyster/ clamshells, algae, shark cartilage, and chelated calcium products (Table 1$)^{10}$. In addition, calcium from marine organisms has good bioavailability and biological function. Reusing by-products from marine organisms can increase the added calcium value and reduce the risk of environmental pollution. For the development of calcium supplements, future work should focus on the comprehensive utilization of proteins, collagen, chitin, calcium, and other nutrients in marine organisms and the use of specific active ingredients to increase the bioavailability of calcium. In other applications, research must likely focus on the transformation of marine calcium into health foods, new materials, or food additives to expand to a commercial scale.

Received: 1 July 2020; Accepted: 12 October 2020

Published online: 28 October 2020

\section{References}

1. Shojaeian, Z., Sadeghi, R. \& Latifnejad, R. R. Calcium and vitamin D supplementation effects on metabolic factors, menstrual cycles and follicular responses in women with polycystic ocvary syndrome: A systematic review and meta-analysis. Caspian J. Intern. Med. 10, 359-369 (2019).

2. Ong, A. M., Kang, K., Weiler, H. A. \& Morin, S. N. Fermented milk products and bone health in postmenopausal women: A systematic review of randomized controlled trials, prospective cohorts, and case-control studies. Adv. Nutr. 11, 251-265 (2020).

3. Kim, S. K., Ravichandran, Y. D. \& Kong, C. S. Applications of calcium and its supplement derived from marine organisms. Crit. Rev. Food Sci. 52, 469-474 (2012). 
4. Blumberg, J. B., Frei, B. B., Fulgoni, V. L., Weaver, C. M. \& Zeisel, S. H. Impact of frequency of multi-vitamin/multi-mineral supplement intake on nutritional adequacy and nutrient deficiencies in US adults. Nutrients 9, 849 (2017).

5. Fischer, V., Haffner-Luntzer, M., Amling, M. \& Ignatius, A. Calcium and vitamin D in bone fracture healing and post-traumatic bone turnover. Eur. Cells Mater. 35, 365-385 (2018).

6. Lee, Y. K. et al. Low calcium and vitamin D intake in Korean women over 50 years of age. J. Bone Miner. Metab. 35, 522-528 (2017).

7. Weaver, C. M., Bischoff-Ferrari, H. A. \& Shanahan, C. J. Cost-benefit analysis of calcium and vitamin D supplements. Arch. Osteoporos. 14, 50 (2019).

8. Wilson, R. L. et al. Reduced dietary calcium and vitamin D results in preterm birth and altered placental morphogenesis in mice during pregnancy. Reprod. Sci. 27, 1330-1339 (2020).

9. Kim, O. H. et al. High-phytate/low-calcium diet is a risk factor for crystal nephropathies, renal phosphate wasting, and bone loss. ELife. 9, e52709 (2020).

10. Jarosz, M. \& Rychlik, E. P-184-calcium and vitamin D intake and colorectal cancer morbidity rates in Poland. Ann. Oncol. 30, v50 (2019).

11. Reid, I. R., Bristow, S. M. \& Bolland, M. J. Calcium supplements: Benefits and risks. J. Intern. Med. 278, 354-368 (2015).

12. Kim, M. Mercury, cadmium and arsenic contents of calcium dietary supplements. Food Addit. Contam. 21, 763-767 (2004).

13. Ross, E. A., Szabo, N. J. \& Tebbett, I. R. Lead content of calcium supplements. JAMA 284, 1425-1429 (2000).

14. Kim, Y., Rodriguez, A. E. \& Nowzari, H. The risk of prion infection through bovine grafting materials. Clin. Implant. Dent. R. 18, 1095-1102 (2016).

15. Kim, Y., Nowzari, H. \& Rich, S. K. Risk of prion disease transmission through bovine-derived bone substitutes: A systematic review. Clin. Implant. Dent. R. 15, 645-653 (2013).

16. Lecerf, J. M. et al. Effects of two marine dietary supplements with high calcium content on calcium metabolism and biochemical marker of bone resorption. Eur. J. Clin. Nutr. 62, 879-884 (2008).

17. Flammini, L. et al. Hake fish bone as a calcium source for efficient bone mineralization. Int. J. Food Sci. Nutr. 67, 265-273 (2016).

18. Nielsen, B. D., Cate, R. E. \& O Connor-Robison, C. I. A marine mineral supplement alters markers of bone metabolism in yearling arabians. J. Equine Vet. Sci. 30, 419-424 (2010).

19. Pateiro, M. et al. Nutritional profiling and the value of processing by-products from gilthead sea bream (Sparus Aurata). Mar. Drugs 18, 101 (2020).

20. Toppe, J., Albrektsen, S., Hope, B. \& Aksnes, A. Chemical composition, mineral content and amino acid and lipid profiles in bones from various fish species. Comp. Biochem. Physiol. B Biochem. Mol. Biol. 146, 395-401 (2007).

21. Patwardhan, U. N., Pahuja, D. N. \& Samuel, A. M. Calcium bioavailability: An in vivo assessment. Nutr. Res. 21, 667-675 (2001).

22. Edmonds, J. S., Shibata, Y., Lenanton, R. C. J., Caputi, N. \& Morita, M. Elemental composition of jaw cartilage of gummy shark mustelus antarcticus Günther. Sci. Total Environ. 192, 151-161 (1996).

23. Chakraborty, P., Sahoo, S., Bhattacharyya, D. K. \& Ghosh, M. Marine lizardfish (Harpadon nehereus) meal concentrate in preparation of ready-to-eat protein and calcium rich extruded snacks. J. Food Sci. Technol. 57, 338-349 (2020).

24. Stewart-Sinclair, P. J., Last, K. S., Payne, B. L. \& Wilding, T. A. A global assessment of the vulnerability of shellfish aquaculture to climate change and ocean acidification. Ecol. Evol. 10, 3518-3534 (2020).

25. FAO. The State of World Fisheries and Aquaculture 2018 (FAO, Rome, 2018).

26. Petenuci, M. E. et al. Fatty acid concentration, proximate composition, and mineral composition in fishbone flour of Nile Tilapia. Arch. Latinoam. Nutr. 58, 87-90 (2008).

27. Fujita, T., Fukase, M., Miyamoto, H., Matsumoto, T. \& Ohue, T. Increase of bone mineral density by calcium supplement with oyster shell electrolysate. Bone Miner. 11, 85-91 (1990).

28. Miura, T., Takayama, Y. \& Nakano, M. Effect of shellfish calcium on the apparent absorption of calcium and bone metabolism in ovariectomized rats. Biosci. Biotech. Bioch. 63, 40-45 (1999).

29. Kandra, P., Challa, M. M. \& Jyothi, H. K. Efficient use of shrimp waste: Present and future trends. Appl. Microbiol. Biot. 93, 17-29 (2012).

30. Gbenebor, O. P., Adeosun, S. O., Lawal, G. I. \& Jun, S. Role of $\mathrm{CaCO}_{3}$ in the physicochemical properties of crustacean-sourced structural polysaccharides. Mater. Chem. Phys. 184, 203-209 (2016).

31. Ding, H., Lv, L., Wang, Z. \& Liu, L. Study on the "glutamic acid-enzymolysis" process for extracting chitin from crab shell waste and its by-product recovery. Appl. Biochem. Biotech. 190, 1074-1091 (2020).

32. Laine, J., Labady, M., Albornoz, A. \& Yunes, S. Porosities and pore sizes in coralline calcium carbonate. Mater. Charact. 59, $1522-1525$ (2008).

33. Reddy, P. N., Lakshmana, M. \& Udupa, U. V. Effect of Praval bhasma (Coral Calx), a natural source of rich calcium on bone mineralization in rats. Pharmacol. Res. 48, 593-599 (2003).

34. Banu, J. et al. Dietary coral calcium and zeolite protects bone in a mouse model for postmenopausal bone loss. Nutr. Res. 32, 965-975 (2012).

35. Marsham, S., Scott, G. W. \& Tobin, M. L. Comparison of nutritive chemistry of a range of temperate seaweeds. Food Chem. 100, 1331-1336 (2007).

36. Brennan, O. et al. A natural, calcium-rich marine multi-mineral complex preserves bone structure, composition and strength in an ovariectomised rat model of osteoporosis. Calcified Tissue Int. 101, 445-455 (2017).

37. Jacobs, R., Gordon, M. \& Jerina, M. Feeding a seaweed-derived calcium source versus calcium carbonate on physiological parameters of horses. J. Equine Vet. Sci. 76, 83 (2019).

38. Yamaguchi, M., Hachiya, S., Hiratuka, S. \& Suzuki, T. Effect of marine algae extract on bone calcification in the femoral-metaphyseal tissues of rats: Anabolic effect of sargassum horneri. J. Health Sci. 47, 533-538 (2001).

39. Uenishi, K. et al. Fractional absorption of active absorbable algal calcium (AAACA) and calcium carbonate measured by a dual stable-isotope method. Nutrients 2, 752-761 (2010).

40. Li, K. et al. The good, the bad, and the ugly of calcium supplementation: A review of calcium intake on human health. Clin. Interv. Aging 13, 2443-2452 (2018).

41. Fujita, T., Ohue, T., Fujii, Y., Miyauchi, A. \& Takagi, Y. Heated oyster shell-seaweed calcium (AAACA) on osteoporosis. Calcif. Tissue Int. 58, 226-230 (1996).

42. Tsugawa, N. et al. Bioavailability of calcium from calcium carbonate, dl-calcium lactate, l-calcium lactate and powdered oyster shell calcium in vitamin d-deficient or -replete rats. Biol. Pharm. Bull. 18, 677-682 (1995).

43. Huo, J., Deng, S., Xie, C. \& Tong, G. Preparation and biological efficacy of haddock bone calcium tablets. Chin. J. Oceanol. Limn. 28, 371-378 (2010).

44. Vavrusova, M. \& Skibsted, L. H. Calcium nutrition. Bioavailability and fortification. LWT Food Sci. Technol. 59, 1198-1204 (2014).

45. Capozzi, A., Scambia, G. \& Lello, S. Calcium, vitamin D, vitamin K2, and magnesium supplementation and skeletal health. Maturitas 140, 55-63 (2020).

46. Bailey, R. L. et al. Estimation of total usual calcium and vitamin D intakes in the United States. J. Nutr. 140, 817-822 (2010).

47. Palermo, A. et al. Calcium citrate: From biochemistry and physiology to clinical applications. Rev. Endocr. Metab. Dis. 20, 353-364 (2019).

48. Hanzlik, R. P., Fowler, S. C. \& Fisher, D. H. Relative bioavailability of calcium from calcium formate, calcium citrate, and calcium carbonate. J. Pharmacol. Exp. Ther. 313, 1217-1222 (2005). 
49. Wiria, M. et al. Relative bioavailability and pharmacokinetic comparison of calcium glucoheptonate with calcium carbonate. Pharmacol. Res. Perspect. 8, e589. https://doi.org/10.1002/prp2.589 (2020).

50. Straub, D. A. Calcium supplementation in clinical practice: A review of forms, doses, and indications. Nutr. Clin. Pract. 22, 286-296 (2007).

51. Liu, J., Wang, J. \& Guo, Y. Effect of collagen peptide, alone and in combination with calcium citrate, on bone loss in tail-suspended rats. Molecules 25, 782. https://doi.org/10.3390/molecules25040782 (2020).

52. Liu, J. et al. Combined oral administration of bovine collagen peptides with calcium citrate inhibits bone loss in ovariectomized rats. PLoS One 10, e135019 (2015).

53. Choi, J. S. et al. Effect of polycalcium, a mixture of polycan and calcium lactate-gluconate in a 1:9 weight ratio, on rats with surgeryinduced osteoarthritis. Exp. Ther. Med. 9, 1780-1790 (2015).

54. Choi, J. S. et al. Antiosteoporotic effects of polycan in combination with calcium lactate-gluconate in ovariectomized rats. Exp. Ther. Med. 8, 957-967 (2014).

55. Wang, X. et al. Preparation of cucumber seed peptide-calcium chelate by liquid state fermentation and its characterization. Food Chem. 229, 487-494 (2017).

56. Bajaj, M., Freiberg, A., Winter, J., Xu, Y. \& Gallert, C. Pilot-scale chitin extraction from shrimp shell waste by deproteination and decalcification with bacterial enrichment cultures. Appl. Microbiol. Biot. 99, 9835-9846 (2015).

57. Tang, S. et al. Preparation of a fermentation solution of grass fish bones and its calcium bioavailability in rats. Food Funct. 9, 4135-4142 (2018).

58. Wang, L. et al. Isolation of a novel calcium-binding peptide from wheat germ protein hydrolysates and the prediction for its mechanism of combination. Food Chem. 239, 416-426 (2018).

59. Wu, W. et al. Preparation process optimization of pig bone collagen peptide-calcium chelate using response surface methodology and its structural characterization and stability analysis. Food Chem. 284, 80-89 (2019).

60. Zhao, L. et al. Isolation and identification of a whey protein-sourced calcium-binding tripeptide Tyr-Asp-Thr. Int. Dairy J. 40, 16-23 (2015).

61. Shankar, K. M. S., Raizada, P. \& Jain, R. A randomized open-label clinical study comparing the efficacy, safety, and bioavailability of calcium lysinate with calcium carbonate and calcium citrate malate in osteopenia patients. J. Orthop. Case Rep. 8, 15-19 (2018).

62. Guo, L. et al. Food protein-derived chelating peptides: Biofunctional ingredients for dietary mineral bioavailability enhancement. Trends Food Sci. Tech. 37, 92-105 (2014).

63. Liu, F. R., Wang, L., Wang, R. \& Chen, Z. X. Calcium-binding capacity of wheat germ protein hydrolysate and characterization of peptide-calcium complex. J. Agric. Food Chem. 61, 7537-7544 (2013).

64. Zhao, L., Huang, S., Cai, X., Hong, J. \& Wang, S. A specific peptide with calcium chelating capacity isolated from whey protein hydrolysate. J. Funct. Foods 10, 46-53 (2014).

65. Hou, H. et al. A novel calcium-binding peptide from antarctic krill protein hydrolysates and identification of binding sites of calcium-peptide complex. Food Chem. 243, 389-395 (2018).

66. Sun, N., Jin, Z., Li, D., Yin, H. \& Lin, S. An exploration of the calcium-binding mode of egg white peptide, Asp-His-Thr-Lys-Glu, and in vitro calcium absorption studies of peptide-calcium complex. J. Agric. Food Chem. 65, 9782-9789 (2017).

67. Kim, S. K. \& Jung, W. K. Beneficial effect of teleost fish bone peptide as calcium supplements for bone mineralization. Adv. Food Nutr. Res. 65, 287-295 (2012).

68. Peng, Z., Hou, H., Zhang, K. \& Li, B. Effect of calcium-binding peptide from pacific cod (Gadus Macrocephalus) bone on calcium bioavailability in rats. Food Chem. 221, 373-378 (2017).

69. Jung, W. K., Lee, B. J. \& Kim, S. K. Fish-bone peptide increases calcium solubility and bioavailability in ovariectomised rats. Br. J. Nutr. 95, 124-128 (2006).

70. Lin, J., Cai, X., Tang, M. \& Wang, S. Preparation and evaluation of the chelating nanocomposite fabricated with marine algae Schizochytrium sp. protein hydrolysate and calcium. J. Agric. Food Chem. 63, 9704-9714 (2015).

71. Guo, H., Hong, Z. \& Yi, R. Core-shell collagen peptide chelated calcium/calcium alginate nanoparticles from fish scales for calcium supplementation. J. Food Sci. 80, N1595-N1601 (2015).

72. Bae, Y. J. et al. Magnesium supplementation through seaweed calcium extract rather than synthetic magnesium oxide improves femur bone mineral density and strength in ovariectomized rats. Biol. Trace Elem. Res. 144, 992-1002 (2011).

73. Hirota, Y. \& Sugisaki, T. Effects of the coral calcium as an inhibitory substance against colon cancer and its metastasis in the lungs. Nutr. Res. 20, 1557-1567 (2000).

74. Ripamonti, U., Crooks, J., Khoali, L. \& Roden, L. The induction of bone formation by coral-derived calcium carbonate/hydroxyapatite constructs. Biomaterials 30, 1428-1439 (2009).

75. Mader, J. et al. Calcium spirulan derived from spirulina platensis inhibits herpes simplex virus 1 attachment to human keratinocytes and protects against herpes labialis. J. Allergy Clin. Immunol. 137, 197-203 (2016).

76. Hou, C. et al. Coral calcium hydride prevents hepatic steatosis in high fat diet-induced obese rats: A potent mitochondrial nutrient and phase II enzyme inducer. Biochem. Pharmacol. 103, 85-97 (2016).

77. Ueda, Y., Kojima, T. \& Oikawa, T. Hippocampal gene network analysis suggests that coral calcium hydride may reduce accelerated senescence in mice. Nutr. Res. 31, 863-872 (2011).

78. Ueda, Y., Nakajima, A. \& Oikawa, T. Hydrogen-related enhancement of in vivo antioxidant ability in the brain of rats fed coral calcium hydride. Neurochem. Res. 35, 1510-1515 (2010).

79. Jung, S. J. et al. Bactericidal effect of calcium oxide (scallop-shell powder) against pseudomonas aeruginosa biofilm on quail egg shell, stainless steel, plastic, and rubber. J. Food Sci. 82, 1682-1687 (2017)

80. Chen, Y. et al. Inhibition of 4NQO-induced oral carcinogenesis by dietary oyster shell calcium. Integr. Cancer. Ther. 15, 96-101 (2016).

81. Terzioglu, P., Ogut, H. \& Kalemtas, A. Natural calcium phosphates from fish bones and their potential biomedical applications. Mater. Sci. Eng. C Mater. Biol. Appl. 91, 899-911 (2018).

82. Shen, Y. et al. Engineering scaffolds integrated with calcium sulfate and oyster shell for enhanced bone tissue regeneration. ACS Appl. Mater. Inter. 6, 12177-12188 (2014).

83. Naga, S. M., El-Maghraby, H. F., Mahmoud, E. M., Talaat, M. S. \& Ibrhim, A. M. Preparation and characterization of highly porous ceramic scaffolds based on thermally treated fish bone. Ceram. Int. 41, 15010-15016 (2015).

84. Rocha, J. H. G. et al. Scaffolds for bone restoration from cuttlefish. Bone 37, 850-857 (2005).

85. Bramhe, S., Kim, T. N., Balakrishnan, A. \& Chu, M. C. Conversion from biowaste venerupis clam shells to hydroxyapatite nanowires. Mater. Lett. 135, 195-198 (2014).

86. Brennan, O., Stenson, B., Widaa, A., O Gorman, D. M. \& O Brien, F. J. Incorporation of the natural marine multi-mineral dietary supplement aquamin enhances osteogenesis and improves the mechanical properties of a collagen-based bone graft substitute. J. Mech. Behav. Biomed. 47, 114-123 (2015).

87. Shi, P. et al. Characterization of natural hydroxyapatite originated from fish bone and its biocompatibility with osteoblasts. Mater. Sci. Eng. C Mater. Biol. Appl. 90, 706-712 (2018).

88. Dai, L. et al. Calcium-rich biochar from crab shell: An unexpected super adsorbent for dye removal. Bioresour. Technol. 267, 510-516 (2018).

89. Dai, L. et al. Calcium-rich biochar from the pyrolysis of crab shell for phosphorus removal. J. Environ. Manag. 198, 70-74 (2017). 
90. You, W. et al. Functionalized calcium silicate nanofibers with hierarchical structure derived from oyster shells and their application in heavy metal ions removal. Phys. Chem. Chem. Phys. 18, 15564-15573 (2016).

91. Piccirillo, C. et al. Hydroxyapatite-based materials of marine origin: A bioactivity and sintering study. Mat. Sci. Eng. C 51, 309-315 (2015).

92. Teixeira, C. M. A. et al. Effect of preparation and processing conditions on UV absorbing properties of hydroxyapatite- $\mathrm{Fe}_{2} \mathrm{O}_{3}$ sunscreen. Mat. Sci. Eng. C 71, 141-149 (2017).

93. Zhu, Z., Lanier, T., Farkas, B. \& Li, B. Transglutaminase and high pressure effects on heat-induced gelation of alaska pollock (Theragra Chalcogramma) surimi. J. Food Eng. 131, 154-160 (2014).

94. Choi, J. S., Lee, H. J., Jin, S. K., Lee, H. J. \& Choi, Y. I. Effect of oyster shell calcium powder on the quality of restructured pork ham. Korean J. Food Sci. Technol. 34, 372-377 (2014).

95. Jun, J. Y. et al. Effects of crab shell extract as a coagulant on the textural and sensorial properties of tofu (soybean curd). Food Sci. Nutr. 7, 547-553 (2019).

\section{Acknowledgements}

The research was supported by Public Projects of Zhejiang Province (2017C32098, LGN20C200003) and Wenzhou Science and Technology Project (ZD202003, N20180011, N20190017). We thank Editage (https://www. editage.cn/) for linguistic assistance during the preparation of this manuscript.

\section{Author contributions}

Conceptualization, L.S. and D.Z.; investigation, J.Y.; writing-original draft preparation, Y.X. and J.Y.; writingreview and editing, Y.X.; supervision, D.Z.; project administration, L.S.; funding acquisition, L.S. All authors have read and approved the final version of the manuscript.

\section{Competing interests}

The authors declare no competing interests.

\section{Additional information}

Correspondence and requests for materials should be addressed to L.S.

Reprints and permissions information is available at www.nature.com/reprints.

Publisher's note Springer Nature remains neutral with regard to jurisdictional claims in published maps and institutional affiliations.

(c) (i) Open Access This article is licensed under a Creative Commons Attribution 4.0 International

License, which permits use, sharing, adaptation, distribution and reproduction in any medium or format, as long as you give appropriate credit to the original author(s) and the source, provide a link to the Creative Commons licence, and indicate if changes were made. The images or other third party material in this article are included in the article's Creative Commons licence, unless indicated otherwise in a credit line to the material. If material is not included in the article's Creative Commons licence and your intended use is not permitted by statutory regulation or exceeds the permitted use, you will need to obtain permission directly from the copyright holder. To view a copy of this licence, visit http://creativecommons.org/licenses/by/4.0/.

(C) The Author(s) 2020 